\title{
Dealing with sustainability trade-offs of the compact city in peri- urban planning across European city regions
}

Forthcoming in European Planning Studies 2012

J. (Judith) Westerink (1), D. (Dagmar) Haase (2), A. (Annette) Bauer (2), J. (Joe) Ravetz (3), F. (Françoise) Jarrige (4), C.B.E.M. (Carmen) Aalbers (1)

1) Alterra Wageningen UR, Wageningen, corresponding author judith.westerink@wur.nl

2) Helmholtz Centre for Environmental Research, UFZ, Leipzig

3) Centre for Urban \& Regional Ecology, Manchester University, Manchester

4) SupAgro, Montpellier

\begin{abstract}
The compact city has become a leading concept in the planning of peri-urban areas. The compact city concept is often advocated as 'sustainable', because of claims that include lower emissions and conservation of the countryside. The literature shows, however, that there are certain trade-offs in striving for compaction, especially between environmental and social aspects of sustainability. In this paper, we describe expressions of the compact city concept in the planning practice of several European urban sample regions, as well as policies and developments that contradict the compact city. We look at examples of positive and negative impacts of the compact city that were observed in the sample regions. Further, we discuss attempts by planners to deal with sustainability trade-offs. Being aware that developments in the peri-urban areas are closely connected to those in the inner city, we compare the sample regions in order to learn how the compact city concept has been used in planning peri-urban areas across different contexts in Europe: in Western, Central and Mediterranean Europe, and with growing, stable or declining populations. We conclude with recommendations with respect to balance in applying the compact city concept.
\end{abstract}

Key words: compact city, sustainability, planning strategies, peri-urban, trade-offs, city region, urban planning, shrinkage, polycentric, spatial concept. 


\section{Introduction}

C.S. Lewis's allegory The Great Divorce (1945) starts in The Grey Town, a depressing place. The city centre is dead and depopulated due to migration to the fringe, as people cannot live in peace with their neighbours. They keep moving away from each other and as a result the city is ever-expanding. In The Great Divorce, The Grey Town stands for hell.

This negative association is probably recognizable for many planners and geographers when they think of urban sprawl. Massive suburbanisation after World War II triggered the emergence of the Compact City ideal, just as the Garden City was a reaction to the overcrowded cities of the $19^{\text {th }}$ century (Breheny, 1996). Today, the compact city is a leading concept in urban (and regional) planning (Calthorpe, 1993; Duany et al., 2000). The question that is of interest here, is the applicability of this ideal to real-life, existing city regions. How do planners put the concept into practice and what unwanted implications do they encounter when they do so? For this, we will look at some of the city regions that were case studies in PLUREL, a $6^{\text {th }}$ Framework European integrated research project that studied peri-urban landuse relations. Peri-urban landscapes are greatly influenced by urban planning policies - or their absence. Protection of the periurban landscape, the transition zone between 'urban' and 'rural' areas, is one of the oftenused arguments for the compact city. The sample regions in this paper are Western, (postsocialist) Central and Southern European city regions. They represent different landscapes, city region typologies and planning cultures. We analyse similarities and differences in terms of dealing with the normative concepts of compactness and 
sustainability. We are convinced that this enables us to draw a general line in the final conclusions of the paper that will be of value in the debate about sustainable urban and peri-urban development. To our best knowledge, an international comparison of compaction strategies in city regions has not yet been made.

First we introduce several aspects and variants of the compact city concept. This is needed to be able to recognise compact city thinking in planning practice. Then we ask ourselves whether it is justified for the compact city to be a 'self-evident' planning objective: is it truly the most sustainable option? This will help us to understand why many governments strive for urban containment, and to look for measures in planning practice for dealing with unwanted implications of the compact city. Having examined the sustainability of the compact city, we present our research question and our research methods. Then we look at some contrasting sample regions: shrinking, growing, all polycentric, but with different population densities and planning histories: Leipzig-Halle,

Greater Manchester, Montpellier Agglomération and the Hague Region. The results obtained from these sample regions are compared and analysed. We conclude this paper with recommendations for the application of the compact city concept.

\section{Compact city concepts}

The compact city paradigm is based on concepts of efficient landuse and urban containment, but includes alongside this a number of goals and parameters (Williams, 1999):

- Urban containment, separation of settlements, efficiency of landuse, 
- Viability of public transport, lower car dependency, lower travel costs and climate change emissions, public health benefits of non-motorized travel,

- Protection of the countryside, land for agriculture, ecological diversity,

- Densification of urban neighbourhoods: together with indirect effects such as social mixing, social cohesion, economic diversity, etc.

The containment agenda is a reaction to 'land consumption' by spread-out suburban city expansions, which were in turn both a deliberate reaction to the unhealthy and crowded cities of the industrial age, and a natural effect of a growing car ownership (Breheny, 1996; Ravetz, 2000). In the nineteen seventies, Dantzig and Saaty published their 'Plan for a Liveable Urban Environment' (Dantzig \& Saaty, 1973). Since then, the compact city has been a leading concept in urban planning, especially in Europe (Häußermann \& Haila, 2004). The compact city leaves space for countryside, for agriculture, nature and recreation. It includes a clear distinction between the city and the countryside in physical appearance and landuse functions: the countryside as 'counterbalance' for the city. It is a spatial concept, which is - although based on historical urban forms - hardly ever fully reflected in the appearance of today's cities. Spatial concepts express, in a condensed and synthesised form, through words and images how people would look at the intended spatial organisation of an area (Zonneveld, 2005). As a concept the compact city is related to a range of concepts about urban form, traffic and liveability. We briefly summarise them here, because they should be born in mind when evaluating expressions of compact city thinking in planning practice in city regions. The summary shows among other things that spatial concepts are not stable over time (Hajer \& Zonneveld, 2000) and 
that the compact city as a form concept was translated into economic and social concepts. Over the past decades a wide field of interpretations and reflections has developed that for our purpose we call the compact city paradigm.

We start our summary with the range of concepts representing the green side of the urban frontier. The idea behind these concepts is to establish and preserve nearby landscape quality and recreational space for the city dweller. Concepts vary from Green Belts (UK, Poland, Russia, around cities), Buffers (Netherlands, between two cities) and Green Wedges (Copenhagen, Amsterdam, between urban districts from the outside in) to a Green Heart (Netherlands, Pennines (UK), surrounded by cities). They all represent a clear distinction between urban and rural (or at least 'green') landuse and are designed to stimulate or enforce urban containment and therefore complement the compact city.

The standard image of the compact city is that of a single city. However, not all cities are monocentric; polycentric cities or urban regions exist and polycentrism has even been advocated as a sustainable urban form. For instance in The Netherlands, 'clustered deconcentration' (gebundelde deconcentratie) was an official concept in Dutch planning in the nineteen seventies (Zonneveld \& Verwest, 2005), aiming at 'a designed development of towns in the direct sphere of influence of urban areas' in order to combine preservation of the countryside with the demand for suburban living. Owens and Rickaby (1992) call this concept 'decentralised concentration'. Related is the concept of satellite cities (Thomas \& Cousins, 1996). The idea of satellite cities is connected to the discussion of the optimal city size (Capello \& Camagni, 2000). A compact city loses 
many advantages if the distance between the core and the fringe becomes too great. The interrelationships between towns in polycentric regions, or even between urban regions, is considered in the concept of 'urban networks' (Zonneveld \& Verwest, 2005).

The compact city concept in its original form was based on the idea of proximity. In compact cities, the daily needs of residents and workers should be within walking or easy cycling distance. The focus on proximity has gradually been replaced by a focus on accessibility (Zonneveld, 2005). The accessibility idea leaves room for a polycentric interpretation of the compact city in which travelling time has become more important than distance. One of the most influential traffic concepts that evolved in the compact city family is Transit Oriented Development (Calthorpe, 1993). This concept promotes integrating transport into urban planning and concentrating development around accessible locations. As we see, the compact city concept is closely related to mobility. There is no compact city concept without emphasis on public transport, or more specifically, a reduced need for transportation by car. Some even advocate a 'car-free city' (e.g. the World Carfree Network). However, commuting behaviour and patterns are changing, since work locations are suburbanizing just as residential areas did earlier (Aguilera \& Mignot, 2004). Subcentres are of growing importance for employment in addition to 'the' city centre.

From an economic point of view, connection and accessibility are key ideas, leading to concepts such as 'concentration', 'corridors' and 'metropolitan networks' (Zonneveld \& Verwest, 2005). Urban forms based on these economic spatial concepts may differ from 
the 'classic' compact city. However, they also reflect a tendency to concentrate. A clear example is the Central Places concept as it was introduced in Germany (see the LeipzigHalle case study in section 5).

The compact city is inseparable from density and/ or intensity, since it strives for concentration of buildings, people and activities. Density is used as a measure for defining urbanity gradients (Loibl \& Köstl, 2010): the denser, the more urban. Density can be defined in different ways: in number of people per hectare, in number of addresses per hectare, in square meters per hectare, or, as advocated by Koomen et al. (2009), urban volume. Density trends can vary according to these different parameters. In many regions, household sizes are decreasing and housing preferences lead to increasing floor space. This means that the number of people in an area may decrease while the built area remains the same or even increases. Another reason for caution with measuring and comparing densities, is that density and compactness are matters of scale (Neuman, 2005) and of framing the area of study.

High densities do not always mean a condemnation to high-rise, as was shown by Uytenhaak and Mensink (2008), Scoffham and Vale (1996) and Sonne (2009), among others. High-rise may not even be efficient, because it limits the access of light to the lower storeys and therefore demands slender buildings or much space in between. Uytenhaak and Mensink show various design principles that may add to the quality of compact cities. 
Where density is a quantitative measure, intensity addresses the use of space and therefore is a qualitative measure of urbanity. However, density and intensity are often used as synonyms. Intensification was defined by Williams et al. (1996) as related to both built form and activity. In their view, built form intensification includes redevelopment of existing buildings or previously developed sites, and development on previously undeveloped urban land. Activity intensification is defined as the increased use of existing buildings or sites. The principle of high intensity implies multilevel and multifunctional urban landuse. Haccou et al. (2007) mention four types of multifunctional landuse: interweaving, intensifying, layering and timing. Interweaving combines functions on the same piece of land; intensifying increases the effectiveness and efficiency of a certain landuse; layering mixes functions in the vertical dimension; and timing uses the same building or space for different functions at different moments.

Finally, we would like to address the concept of the social city. The Social City Region (Breheny, 1993; Ravetz, 2000) is an attempt to deal with the complexity of reshaping existing cities, aiming for varying standards (e.g. densities) to suit differing but complementary conditions. In Germany, the Social City Programme was worked out, which supports integrated local concepts for revitalising city quarters, combining community work and urban planning (Evers et al., 2006). The social city aims to create an attractive and liveable urban environment and community that will attract people into the city instead of pushing them towards the suburbs due to lack of quality of houses, public space and facilities. 


\section{Why or why not opt for the compact city? Pros and cons of the compact city and the assumption of sustainability}

Many planners and policy makers use the compact city concept because of its aim of sustainable development: lower energy use, less land consumption and more liveable cities. Among researchers there are strong advocates of the compact city as well (EEA, 2006), although there are also many critics. Among other things, the compact city is stated to be unfeasible, its environmental benefits unlikely, its social costs undesirable and some greenfield development inevitable (summarized in (Breheny, 1996).

The theoretical compact city, and its opposite, the theoretical dispersed city, have certain characteristics, which are summarised in Table 1. This overview aims to summarise the discussion rather than to prove or disprove any of the theories involved. Solid scientific proof of the sustainability of the compact city may even be unfeasible because both concepts (compact city and sustainability) have not been sufficiently defined for that purpose (their character as 'empty signifiers' may even explain their success). However, the literature was obviously used as a starting point (Adolphson, 2010; Bogunovich, 2009; Bramley et al., 2009; Breheny, 1996; Breheny, 1997; Burton, 2001; Gordon \& Richardson, 1997; Häußermann \& Haila, 2004; Hillman, 1996; Holden, 2004; Howley, 2009; Howley, 2010; Howley et al., 2009; Jenks \& Burton, 1996; Lin \& Yang, 2006; Stretton, 1996; Van Der Waals, 2000).

(Table 1 app. here) 
Table 1 suggests that the claim that 'the compact city is more sustainable' is too simple, in line with Jenks et al. (1996), Williams (1999) and Van der Waals (2000). Both concepts have weaknesses and strengths with respect to sustainability. Compact urban forms may be more sustainable for some issues, but less so for other. We call this 'sustainability trade-offs': a gain in one sustainability dimension may be accompanied by a loss in another dimension. Overall, the compact city seems favourable with respect to many of the environmental criteria (except for urban air quality and urban heat), but it comes with social constraints and higher construction costs. Strategies for dealing with these social and the few environmental constraints include urban renewal, limitations on car use, mixed landuse and life cycle residential strategies. In the case studies, we will look for strategies like these to see if planners are aware of the sustainability trade-offs in the compact city concept and how they tackle them. This leads to the following research question:

In what ways is the compact city paradigm expressed in peri-urban planning in European city regions and how are sustainability trade-offs dealt with?

\section{Research approach}

In this paper, we use case studies to get insight in the complexity of applying a general concept like the compact city to real-life cities. The empirical material was produced in the PLUREL case studies between 2007 and 2010. In these sample regions, the way that regional governments and other actors steer landuse in the urban fringe is studied by

analysing their strategies. Strategies are designed successions of decisions and actions of an actor to achieve objectives (Aalbers \& Van Dijk, 2007). Primary data collection in the 
case studies included interviews and discussions with pre-selected stakeholders in landuse development and planning. In the interviews, the stakeholders were asked about their perceptions of the peri-urban area, their objectives with this area and their strategies for achieving these objectives. In some of the case studies, action research was done to get an even deeper insight into the actors' way of working, by attending meetings, participating in events, following policy development and in one case even co-developing a strategy.

The secondary sources of information drawn on for this paper were policy documents, maps, statistical data and scientific literature. Further information on the research methods for the sample regions can be found in Aalbers and Van Dijk (2007). For this paper, the case study material was reviewed again from the perspective of the use of the compact city concept. The different compact city concepts of chapter 2 , the sustainability trade-offs of chapter 3 and the strategies applied were used as 'probes' for the cross-case study comparison.

The four cases (Montpellier Agglomération, Leipzig-Halle, Greater Manchester and The Hague Region) are suitable for this kind of analysis because they are both contrasting and similar. They are all EU city regions of considerable size, facing peri-urbanisation and making policy aimed at sustainable urban development. They are different however in urban dynamics, landscape and planning culture. In Table 2 some figures are presented related to urban growth and density based on Loibl et al. (2008) and Loibl et al. (2010). The delineation of the regions in these studies of are slightly different from the case 
studies described below, but the figures give a general impression of the differences between the regions. In the Rotterdam-Haaglanden region, the urban fabric area had the largest growth between 1990 and 2000, but the region still has the lowest urban land consumption per capita. Manchester-Liverpool has the highest TCAI, however, indicating a high level of compactness. Montpellier is the most sprawled city, but has the lowest urban extension between 1990 and 2000. Among the case study regions, land consumption per capita is the highest in Leipzig-Halle and the value for urban densities in the region the lowest, as a result of the still considerable residential vacancy in Leipzig and Halle (see case study section).

(Table 2 app. here)

These different characteristics of the sample regions have a story of urban development and government policies. In the next section, some of this context is told and the ways in which the compact city idea is applied are described, as well as strategies to deal with sustainability trade-offs.

\section{Results: expressions of the compact city paradigm per case study}

\section{Montpellier city region}

Montpellier is the main city of Montpellier city region, a large monocentric region (Loibl et al., 2008) at the French Mediterranean coast. The city and its surrounding towns and villages have associated in 2001 into a large inter-communal corporation of 31 
municipalities - Montpellier Agglomération - with 320,760 people (2007). In the narrow coastal plain, not much agriculture is left. Farmland decreased with $20 \%$ between 1979 and 2000 . With 11,500 ha left, farmland represents $38 \%$ of the whole surface of Montpellier Agglomération in 2000 (Montpellier-Agglomération, 2006). The vineyards in the hills around Montpellier used to be part of the largest area of vine in France. However, crisis in the vine sector since the nineteen seventies led to a massive conversion of vineyards to other landuses. For four decades, Montpellier was a rapidly growing city with technology and tourism as drivers of economic growth (see Table 3). Development was not coordinated and land was cheap, resulting in urban sprawl and high space consumption by individual housing and individual transport. The creation of Montpellier Agglomération brought more coordination in urban development. Montpellier Agglomération was the contracting authority of the 'SCoT' (completed in 2006), the first inter-municipal spatial planning document. The SCoT (Schema de Coherence Territoriale) draws the main development orientations in the 31 participating municipalities of Montpellier Agglomeration for a period of 15 years. The SCoT was made with input of much professional expertise and little citizen involvement.

(Table 3 app. here)

Traditional Languedocian villages presented a compact housing morphology for centuries. In the light of the recent development of urban sprawl, the concept of 'compact city' was presented in the SCoT as a 'renewed vision': 'traditional compact housing has to be revisited with modern architecture concepts'. Compact city thinking is at the heart 
of the SCoT. There is no political will to stop demographic growth, which is the driver of residential economy (economy of services) and the major source of wealth for the city region, but there is a consensus on the necessity to decrease space consumption in order to achieve a more sustainable urban development. Politicians are increasingly aware of the decreasing land stock on the limited littoral plain, with the negative example of the neighbouring city region of Nice (Cote d'Azur) in mind.

The SCoT introduces the following concepts to defend a number of values:

- “a natural city" (environment): preserving natural assets, agriculture, outdoor leisure and landscapes;

- "a shared city" (social value: a "city of proximities"): housing, economy (employment), transport/mobility, (car)parking;

- "an efficient city" (economic value): intensifying development (increasing housing density, improving public transport), sparing space.

For a spatial implementation of this philosophy, the SCoT is designed on the basis of the framework of green spaces (farmland, nature), a framework of public urban transport and delineation of limits and density of urban development (Buyck et al., 2008). For example, an area can be allowed to have three development levels of housing density $(>50,>30$ and $>20$ dwelling units/ha) depending on local context and access to public transport services.

Special attention is paid in the SCoT to farm buildings, since the number of buildings in agricultural areas has grown considerably. In the recent past, it was common practice 
among land owners to use the argument of farming necessity to obtain a farm-building license. These farm buildings were built to be converted into pure housing soon afterwards. To protect open spaces and landscapes, in the SCoT development rights in agricultural areas are strictly limited. To enable 'true' farm development, the model of 'agricultural hamlet' is promoted: a special area dedicated to farm buildings in spatial planning, next to existing developed areas. The agricultural hamlet is supposed to aggregate all new farm buildings in the municipalities of Montpellier Agglomeration. Farm buildings in the agricultural hamlet can be either professional buildings or farm houses. This model was also supposed to put an end to growing neighbour problems between farmers and (new) residents in rural villages due to the traditional location of farm buildings in the heart of the village. Until now, only one agricultural hamlet has been built in Montpellier Agglomeration, with public technical and financial support. It was built in a grape growing village with all farmers being grape growers belonging to a unique wine cooperative. The project raised unexpected difficulties: non farmers demanded more equity in housing opportunities. In a reaction to this, the mayor developed a social housing project "to compensate" for the agricultural hamlet. Although it was social housing, housing costs were still higher for non-farmers than for farmers. Inequities rose between farmers of the hamlet and other farmers and relationships between some farmers and the mayor became tense. When some problems were solved, others emerged, with new annoyances and discomfort for neighbours of the agricultural hamlet. No other agricultural hamlet has been constructed in Montpellier Agglomeration since, because of lack of local consensus in rural villages. The agricultural crisis can also be considered as a limiting factor (Jarrige et al., 2008; Nougarèdes, 2008). 
In the example of the agricultural hamlets, a compact city strategy aiming for a higher landscape quality failed because the social impacts and context were not sufficiently taken into account. The technocratic model was imposed on the community without local consultation and without understanding of the local people's situation and needs or their capacities for building their own "socio-political arrangements". During previous decades, "local arrangements" between farmers and local politicians were made in a reaction to the wine crisis in the region. These arrangements had their legitimacy in that context, but have become largely unsustainable in the current situation, because they have increased the massive pulling out of vineyards to develop individual housing in villages around Montpellier, resulting in widespread urban sprawl.

Summarizing, the absence of urban containment policies in Montpellier enabled urban sprawl and the loss of valuable landscape. However, since the creation of Montpellier Agglomeration and the compilation of a regional planning strategy (SCoT), local governments are more committed to and better equipped for sustainable urban development. The first experiences with planning agricultural hamlets - aimed at preventing sprawl in the peri-urban landscape - illustrate that technocratic or "top-down" solutions might not be the way to achieve sustainable development at local scale and in real-life communities. Theory does not arbitrate between sustainability trade-offs in practice. Local arrangements cannot be considered as the panacea to rely on either, because arbitration among local private interests does not always lead to achieving collective interest. The drawing of the SCoT of Montpellier Agglomeration has been 
useful to improve cooperation between the region's municipalities, and to build capacities of the local planners. In that way it can be considered as a useful tool, a first step in opening consciousness and designing practical solutions for a change towards more sustainable ways of life in Montpellier city region.

\section{Leipzig-Halle}

With a population of 1,073,000 in the year 2008, the city region of Leipzig-Halle is an important agglomeration in Central Germany (SAS, 2010). It is located in the federal states Saxony and Saxony-Anhalt and covers a total of 4,390 $\mathrm{km}^{2}$. Its main urban cores, Leipzig and Halle, are encircled by small towns and rural areas. The Leipzig-Halle region is characterised by strong interrelations in terms of the labour market, the regional economy, housing, consumption and leisure (Sinn et al., 2008).

The Leipzig-Halle region already faced population loss since the nineteen seventies which reached its peak right after the political change in 1990 but continues until present-day (Nuissl \& Rink, 2005). This had a considerable impact on landuse change in the region (Haase \& Nuissl, 2007). Between 1990 and 2006 the study region's inhabitants fell from 1.357.806 to 1.217.264 (-10.4\%) (SAOS, 2010; SAS, 2010). However, the periurban and rural areas show a different pattern than the core cities (Table 4). Overall, the impression is that of a stagnating region. In economic terms, the region shows a decline in investment rates and public finances. Unemployment rates are high: currently (2010) about 20\% (SAS, 2010). 
(Table 4 app. here)

The city of Leipzig is a case that highlights the East German "story of shrinkage and urban comeback". Since the late 1960s, the city experienced a continuous loss of its population, which underwent an acceleration with the onset of the post-socialist transition in 1989. Due to out-migration to western Germany and (strongly subsidised) suburbanisation the population decreased from 530,000 (1989) to 437,000 (1998). Population losses brought about an increase in residential vacancies up to 62,500 vacant flats (20\% of the total stock in Leipzig) in 2000. In late 2005, vacancies decreased to 45,000 flats (14\% of the total stock, Municipality of Leipzig, 2006) due to demolition, a further rise in household numbers and a stabilisation of the population. Demolition produces new spatial patterns. For this, the term "perforation" was introduced by Leipzig urban planners (Lütke-Daldrup, 2001) and is still being discussed since that time (Haase, 2008).

Today (2010), Leipzig's number of inhabitants stands at 513,000 (MoL, 2009) and is expected to grow further. According to the urban cyclical model of Van den Berg et al. (1981), Leipzig has entered the phase of reurbanisation. The old built-up areas in the inner city are affected most, since from 2000 to $200588 \%$ of all in-migrants have moved to these areas. At the same time, out-migration from the city has almost stopped. Reurbanisation, in this sense, refers also to a rising city-mindedness or willingness of people to stay in the city (Haase et al., 2005). Reurbanisation is sustained mainly by 
younger age groups including students, apprentices and young professionals (aged 18$35)$.

Strengthening urban centres is supported by the central places concept in spatial planning. The central places found entry into the spatial development plans of the federal states of Saxony and Saxony-Anhalt, where the cities of Leipzig and Halle are located, as well as into the relevant regional plans (Region of Western Saxony and Halle Region). Such central places, mentioned in the German Regional Planning Act (BdJ, 2010), are to be developed as nodal points of the economy, public utilities and transportation and are the designated focal points of settlement development (LPSA, 2003; LPSAH, 1999). They consist of a hierarchy of centres, ranging from first-order centres with a variety of functions for their surroundings to basic centres supplying a limited range of goods and services to the local population. The clustering of urban activity in 'central places' has economic origins but is now presented as an efficient spatial pattern to provide (public) goods and services (Regional Planning Act $§ 2.2$ ). Even though the central places concept was introduced to spatial planning in Saxony and Saxony-Anhalt in a time of expected economic growth, it was not dismissed when these expectations were not fulfilled. Rather, it was attempted to adapt the concept to a situation of economic decline and population shrinkage by simplifying the hierarchy of centres and emphasising the roles of central places in economic development (LPSA, 2003). Notably, the central places concept is justified without explicit reference to sustainable urban form or to the compact city concept. However, because it promotes the settlement of public utilities and private sector investments in centres and restrict them elsewhere, the central places concept $d e$ 
facto contributes to urban compaction. Thus, we think it is valid to interpreted it as a prominent expression of compact city thinking in spatial planning in the Leipzig-Halle case study.

Besides the central places, further spatial planning aims contribute to compaction. The spatial development plans of Saxony and Saxony-Anhalt for example encourage innercity development or development in the vicinity of existent settlements prior to development in more remote locations, protect unsealed land and prevent urban sprawl (LPSA, 2003; LPSAH, 1999). Both the regional plans for Western Saxony and the Halle Region emphasise the prudent use of greenfield land as a societal resource. This is to be achieved through directing residential development towards central places and axes between them, a focus on inner city development and redevelopment of brownfields (RPH, 2009; RPWS, 2008). An investigation of the perspectives of spatial planners in the Leipzig-Halle region on the development of their region indicates that civil servants from the core cities in particular support the compact city idea (Sinn et al., 2008). As planners from the core cities have limited control on the urban development beyond their jurisdiction, consensus-based strategies for urban containment are sought. A prominent example is the Green Ring of Leipzig initiative, aimed at the preservation and development of the peri-urban landscape. The Green Ring covers diverse landscapes, including forests, urban and fringe green spaces, brownfields, farmland, rivers and floodplains (Bauer, 2010). As spatial concept, it differs from the Green Belts in the UK, because it does not have a zoning status to prevent its urbanization. Rather, it is a program for the promotion of the area, for enhancing the landscape and improving 
recreational infrastructure. Initiated in 1996 by Leipzig planning officials, the Green Ring focused on the restoration of fallow open-cast mines and industrial estates at first. Further areas of responsibility were the management of the remaining cultural landscapes and educational activities. These tasks proved a strong incentive for inter-municipal cooperation (Sinning, 2002). The Green Ring's members are composed of fourteen municipalities with Leipzig, two rural districts, civil society organisations, private firms and individual citizens. Currently, 26 key projects are implemented ranging from afforestation to the signposting of footpaths (GRL, 2010).

The compact city is supported through formal spatial planning in the Leipzig-Halle region, e.g. the central places concept, as well as through informal strategies for the periurban and urban areas, such as the Green Ring of Leipzig initiative, urban renewal and the construction of town houses. Thus, even though other forms of spatial development, such as perforated cities, where observed and discussed, the idea of the compact city maintained credit among planners. After a period of suburbanization combined with population decline, leading to high urban vacancy, urban renewal in form of renovation and the construction of so-called town houses (single houses in villa style) is currently contributing to reurbanisation. This can without doubt be understood as a strategy of the cities of Leipzig and Halle to strengthen the compact character of the their urban cores.

\section{Greater Manchester}

The Manchester sample region is a topical example of compact city spatial planning in action: from a long history of experiments, it shows both planning processes and results 
on the ground (Ravetz, 2008). This unique city-region was one of the birthplaces of the industrial revolution between 1750 and 1850. Later, following the export of most of its heavy industry, it has spent the last 50 years on restructuring and reclamation of large areas of 'DUN' land ('Derelict, Under-used and Neglected'). The regional economic performance is below the national average, but there is a basic level of affluence and organization of public services, with a mostly well-established planning system.

(However at the time of writing in 2010 this is now thrown into uncertainty, as the new UK Coalition government has rapidly taken down most of the regional and strategic planning system).

The Manchester city-region has a complex geography. There is an inner core of 1.2 million people in a mainly continuous urban area. There are another 1.3 million people in a ring of satellite towns and small cities. Each of these together makes up the 'Greater Manchester' political unit of 10 municipalities. There are a further 1.5 million people in a wider 'Rural-Urban-Region' (RUR, the wider functional urban region: the commuting ring and areas providing agricultural produce, nature and recreation to the urban centres), which does not have a single agreed definition. This RUR is adjacent and overlapping with other RURs of Merseyside, West Yorkshire and East Lancashire. The overall density is 1970 persons $/ \mathrm{km}^{2}$ for the inner urban core, and half that in the outer ring: the overall rate of urbanization (i.e. additional to the existing urban area), is $0.2 \%$ per year. On current trends, $30 \mathrm{~km}^{2}$ of rural land would be developed in 2000-2020, and the entire current stock of urban and fringe DUN land would be used up: however there is a 
continuous flow of landuse change at a variety of scales, with new forms of DUN land coming up.

In principle the UK spatial planning system is focused on containing urban growth, recycling urban land, and encouraging 'sustainable communities' (Roberts, 2008). This is done with several main pieces of planning law and practice. The Green Belt policy was established in 1946, and now Green Belts surround all larger cities and conurbations in the UK (Elson et al., 1993; NE \& CPRE, 2009). Other designations, such as 'Area of Landscape Value' etc, have similar effects, although not with such a strong legal basis. Although the Green Belt is seen to be generally successful in its main objective of urban containment, there are many exceptions made in its implementation: these include new roads, infrastructure, business parks, health and education campuses, and in certain cases larger housing developments. Another important instrument is the Planning Policy Statements (PPS), giving national guidelines for interpretation of planning law. The most relevant here is PPS3, which sets a target of $60 \%$ of all new development to be on 'brownfield' (DUN) land (CLG, 2010).

In Greater Manchester, urban containment and densification are not the only policies shaping the urban and peri-urban settlement structure. We can see a range of spatial strategy 'agendas' at a range of scales: from urban and rural orientation, and from a growth or a conservation focus. This range of policy agendas helps to identify problems and opportunities, and where current policies are working, in conflict or missing. Overarching these is the agenda for sustainable development: often fuzzy and complex in 
practice, and often ignored or misused by stakeholders, but still a powerful influence on policy (Ravetz, 2000). Below we look at the application of the compact city principle through these different layers of policy: from the regional level to the urban housing level, from landscape and transport issues to social and community issues.

At the regional level, the North West Spatial Strategy prioritizes the re-use of urban land and containment of urban growth through Green Belt and similar policies (GONW, 2008). Peri-urban areas are mainly seen as 'spaces between' settlements, and hence not on the priority list of development agendas. However in terms of development, these may be seen as 'problem' areas, in that any form of development may detract from open land and landscape. At the urban level there are similar priorities for recycling of urban land, higher densities in existing settlements, and for social housing to be included with private developments. But the pressures for commercial services and industrial development are very strong, so that many out-of-town developments continue to be built. At the landscape level, there is recognition that Green Belt, Areas of Landscape Value and similar policies generally serve their purpose of containment: but there is an apparent lack of positive benefits for land or landscape quality and diversity, a problem which has to be picked up by other policy areas (Wood \& Ravetz, 2000). And for transport, there is a general policy direction in favour of public transport: but in practice there are institutional problems and barriers with a mainly privatized rail and bus system, and road building still claims the majority of transport funding. 
Much of the conurbation landuse is former industrial or infrastructure, now in open space, which is not quite urban or rural: in fact such land is not exactly urban fringe or 'peri-urban'. This can cause planning problems and conflicts. For instance the largest shopping mall in the region, the Trafford Centre, was built on such DUN land where its status was disputed. The planning question for a major Public Inquiry in 1995-6 was whether this was 'urban regeneration' or 'out-of-town' shopping development: in the end it was decided as 'urban', and its construction went ahead.

These and many more examples highlight some of the questions underlying the compact city principle, as put into practice. Will compact towns and cities simply displace their low density infrastructure (retail, leisure, distribution, manufacturing) to outside or to other settlements, and what would be the effects of that? The agenda for economic development often pushes in the opposite direction, in order to satisfy investors and entrepreneurs looking for large greenfield sites with easy road access. This was seen in the area south west of Manchester, where the regional Economic Strategy proposed a growth zone in the Green Belt of Cheshire, an area where housing is strictly prohibited (NWDA, 2009). In addition, many settlements particularly in declining industrial areas, are trying to maintain a social mix and bring in more affluent residents. To do this requires larger houses and gardens, with links to fast roads, and so again the compact city objective can be diluted. Another social question is the relationship of residential density to urban 'liveability', or the capacity of communities for social interaction, inclusion and quality of life. The housing market shows that for the affluent, high density is a trade-off for style and proximity, as in the new 'loft apartments' now surrounding the Manchester 
Central Business District, or the fashionable 'lifestyle-suburbs' in South Manchester (Ward et al., 2010). Otherwise, if lower income people are forced into high density living with few social or economic opportunities, there is potential for a spiral of deprivation, exclusion and anti-social activity: as seen in many public estates around the periphery of the conurbation.

Overall, the Manchester case shows some of the problems in applying the compact city principle in a diverse, complex and problematic conurbation (Ravetz, 1999). Much of the urban area is relatively dense, compact, but at the same time sprawling: much of the land area is urban and at the same time fringe or peri-urban. It is difficult to put precise boundaries to the 'unit of analysis', difficult to define the compactness, and difficult to identify exactly the effects of spatial forms, in combination with many other influences. Such difficulties are shown by the new UK statistical definition of urban and rural: rather than fixed density bands at any one location, this is now based on 'cones' of decreasing density with a range of gradients.

The general finding from the Manchester case study is that spatial development policy, and its interpretation of compact city principles, needs to be more closely linked to other social and economic policies, if it is to make a real contribution to 'sustainable communities'. Overall, the compact city agenda in the UK case seems to be a channel for much wider issues in society - not only 'where' to live, but 'how' and with 'how much?' and not only 'with whom', but especially 'near to whom'? 


\section{The Hague Region}

The Hague Region (Haaglanden) as a city regional authority is a cooperation of nine municipalities, located in the urbanised West of The Netherlands. It is an urban polycentric region (Loibl et al., 2008), with three cities (The Hague, Zoetermeer and Delft) and a number of towns and villages, with in total almost 1 million inhabitants in an area of $410 \mathrm{~km}^{2}$. The Hague is the most densely populated city of the four main cities in the Netherlands with 11.310 inhabitants per $\mathrm{km}^{2}$ built-up area (CBS, 2005). The region is 27,7\% urbanised (2004), including the extensive greenhouse areas. The Hague Region borders the urban regions of Leiden and Rotterdam. Being situated at the North Sea coast, there is little space for expansion. Urban fringe areas in this 'cornered' polycentric region are green peri-urban enclaves rather than fringe areas with a transition to rural areas. The most important planning challenges of the region are quality of life, traffic, availability of open space and protection against excess water both from the sea and from the rivers (Aalbers et al., 2009). Large parts of the region are below sea level. Traditionally, towns were built on higher ground, but the more recent urban expansions and the whole city of Zoetermeer were built in the lower polders due to lack of space and aided by improved construction technology.

As early as the nineteen sixties, large parts of the peri-urban area in the region were protected through the buffer zone policy. Buffer zones, meant to prevent cities from growing together, were integrated into municipal zoning plans and were very successful in keeping urbanisation at bay (van Rij et al., 2008). This philosophy of clearly demarcated, compact cities surrounded by countryside posed The Hague with a problem: 
how to grow? In 1962, the village of Zoetermeer (10.000 inhabitants), some 13

kilometres from The Hague, was designated by the National government as 'growth centre': a satellite city of The Hague, but also a full city in its own right. In 1991 it had 100.000 inhabitants.

Discourses about desirable urban development change, however, and in the nineteen eighties 'clustered deconcentration' was replaced in national policy development by a traditional conception of compact cities (Zonneveld \& Verwest, 2005). City and countryside needed to be separate worlds and recognizable landscapes. According to the Fourth Spatial Development Plan Extra (1993), urban expansion should take place at the edge of existing urban areas, and a large share of construction should be realised inside urban fabric. So, large but concentrated new housing sites were developed adjacent to the larger cities, including The Hague, to meet the demand for affordable houses as well as to prevent uncontrolled suburbanisation of the countryside.

As a result of decentralisation of planning, since 2005 a number of city regions such as The Hague Region were given tasks in coordinating planning between municipalities. In The Hague Region's Housing Strategy (THR, 2004), compact city thinking is dominant. The motto is: 'green, blue and compact'. A compact urban form is linked to preservation of green space and quality of life in the region, with the notion that identity and variety in urban neighbourhoods is a prerequisite. One of the solutions is sought in multifunctional and multilayered landuse. Good public transport is seen as necessary. In their reaction to the Housing Policy document, the three largest municipalities actually characterise their 
city as compact (The Hague, Delft, Zoetermeer). Compact is interpreted as the proximity of a range of services and recreation facilities (Zoetermeer) and as a quality when combined with green urban space (The Hague).

The expression 'compact city' is not mentioned as such in Regional Structure Plan (RSP: (THR, 2008). However, it does mention other related concepts. The RSP refers to the 'Stedenbaan' programme, which is intended to lead to a faster, more frequent and more finely-mazed public transportation system between The Hague, Rotterdam and surrounding cities. Accessibility has replaced proximity as the leading concept. With the goal of preserving the green peri-urban enclaves, the RSP aims at building $80 \%$ of the housing targets within urban fabric. To reach this objective, strategies such as intensive and multiple landuse, efficient landuse and mixing functions (multifunctional landuse) are mentioned. Densification is to be located around the 'Stedenbaan' public transport stations, a pure Transit Oriented Development concept. The areas around the central train stations of The Hague and Delft are already being restructured according to this philosophy.

Not all planning activities in The Hague Region are geared towards the compact city, however. Especially with respect to transportation, no clear choice is being made. Improvements to the public transportation system and cycling routes are planned, but the Regional Structure Plan also aims for a substantial expansion of the road network. This policy mirrors the behaviour of travellers in the region. Public transport use in The Hague is below that of Amsterdam, Rotterdam and Utrecht (see Table 5). Car use by inhabitants 
of Zoetermeer is considerably higher than that of the other cities in the region. The motorways A4 and the A12, both leading into The Hague Region, are in the top four congested highways in The Netherlands (VID, 2008).

(Table 5 app. here)

The effects of the urban containment policy are clearly visible on the map of The Hague Region. It is neatly organised in urban, natural, greenhouse and meadow landscapes and, although the urban influence is tangible, the traditional landscapes and natural areas can therefore still be enjoyed by millions of visitors each year (Briene et al., 2006). Visitors to the peri-urban areas are mainly elderly and few are of foreign origin (ibid). Immigrant groups do not know the peri-urban areas and therefore use them less than native groups (Aalbers et al., 2009). The Hague Region aims to improve the accessibility of the periurban areas for the city dwellers, as there are too few urban parks to meet the demand for recreation (Vries et al., 2011).

Four neighbourhoods of The Hague are part of the national programme 'strong neighbourhoods' ('krachtwijken'). This programme recognizes the relation between public space and social problems. It combines improving housing variety and the quality and safety of public space with youth health, care for multi-problem families, employment and integration of immigrants. Although these projects are not officially connected to compact city policies, they do address possible negative social effects of compact city planning. 
Summarizing, The Hague Region has a long history of urban containment policies which have been fairly effective in preserving some of the green peri-urban areas, but the region's cities have a shortage of urban parks. Multifunctional landuse is one of the recent strategies aiming for landuse efficiency and a high quality of life in the dense inner cities, where space is extremely scarce. Another strategy is improving public transportation, although car use is also facilitated though extension of the road network. With a changing demographic situation, the urban containment policies fail to take into account recreational needs of immigrants.

\section{Discussion}

The sample regions analysed in this paper show a diverse picture with respect to urban layout, population dynamics and planning history. However, all regions apply some form of compact city thinking, as summarized in Table 6. Densification, inner city building and brownfield development is applied by all of them. However, none of the regions aims for a 'traditional' monocentric, circular version of the compact city. They have to deal with the reality of the history of their urban development, population dynamics, the variety in housing preferences and their economic development agenda. All regions therefore use a polycentric/network interpretation of the compact city, such as Leipzig with its 'central places'. Accessibility is an issue in Montpellier and The Hague Region: both regions increase densities around transport nodes, using a Transit Oriented Development approach to compaction. 
(Table 6 app. here)

Comparing the sustainability trade-offs also gives a diverse picture. Montpellier and Leipzig-Halle illustrate that urban sprawl can have negative effects. In the case of a growing city, sprawl leads to landscape degradation, but in the case of a shrinking city, the very life of the city is threatened by urban sprawl. Manchester and The Hague Region illustrate that strong protection of the peri-urban, and containing the city, has risks as well. Who can afford to travel, can provide themselves with a green living environment and green space for leisure. However, the less mobile may be trapped in dense urban districts with insufficient green space (Aalbers \& Eckerberg, 2011). The peri-urban landscapes of Manchester may be 'protected' because of the Green Belt policy, but mere rules fail to improve their quality or to generate economic benefits to the areas themselves. The Hague Region is an example of a region with high densities, but also high traffic congestion. The attempt of Montpellier to prevent urban sprawl by means of agricultural hamlets led to social unrest among farmers and civilians because of differences in building rights and housing prices. In Greater Manchester, some dense housing projects of the past have developed into neighbourhoods with many social problems.

In all sample regions, the trade-off between high densities and quality of life is recognized and strategies have been developed to deal with that. All regions make use of quality criteria for residential areas, varying from a variety in housing for different target groups (Manchester, The Hague Region) to reviving the inner city (Leipzig) and detailed 
design guidelines (Montpellier). Leipzig, in addition, is improving the network of green spaces in the city. The Hague Region tries to stimulate landuse efficiency through multifunctional landuse, a concept that implies the possibility of for instance green space on roofs. Another way in which The Hague Region tries to compensate for the shortage of urban green space, is by improving the accessibility of the peri-urban landscapes.

\section{Conclusions}

Even though the compact city may not be fully applicable to contemporary cities (Graham and Healey, 1999), we see that variants of the concept are widely used in the planning of European city regions. Our sample regions illustrate that the use of compact city thinking is diverse and is expressed in various forms. This is not surprising, since our sample regions are in different development stages and have a diverse planning history. We may conclude that the compact city concept is sufficiently vague and adaptable to allow for variety in interpretation and implementation. However, the traditional, monocentric interpretation of the compact city is not used by the regions studied in this paper.

From the vast amount of literature on the compact city, no clear conclusion can be drawn about its sustainability. Rather, a picture arises of dilemmas and contradictions. The compact city is not an implementable blueprint: therefore planners need to develop more detailed and tailor-made strategies for sustainable development of their own region. However, little guidance is available to planners to balance sustainability contradictions (Williams, 1999). Balance is the main recommendation of Bramley et al. (2009), who 
take quality of life and well-functioning communities as most important indicators. They suggest diversity in urban environments, similar to Breheny (1993). And this is exactly what we see happening in our sample regions: quality, diversity and multi-functionality are the focus of strategies that are combined with urban containment in order to deal with sustainability trade-offs. Apparently, the current generation of planners in our sample regions is well aware of the limitations of the compact city concept.

Lin and Yang (2006) give a number of recommendations for a more sustainable application of compactness, including greening high-density cities. However, such an approach may still be too much 'form' and too little 'process' (Neuman, 2005). Spatial governance and planning policy can be very political: one person's solution is another's problem, and any policy creates winners and losers. The Montpellier case study gave a clear example of a technically sound solution that failed to take into account the complexity of social processes related to landuse change. Compact city strategies (and spatial planning in general) should therefore be accompanied by strategies for communication and involvement.

Urban sprawl is no sustainable direction of development, but striving for compaction is not an easy road either. This paper has shown that a broad interpretation of the compact city concept, including reflections on sustainability trade-offs, is useful in two ways. First, city regions need to be able to adapt the concept to their own situation; and second, narrowing down the compact city idea to high density only is undesirable and does not do justice to the complexity of real-life cities where real people live. 


\section{Acknowledgements}

We would like to thank all our co-workers in the case studies who do not appear as coauthors in this paper. In addition, we are grateful to the stakeholders that participated in the research project. We also thank two anonymous reviewers on their insights and useful comments on how to improve the earlier version of this manuscript. The research was done in the Integrated Project PLUREL (Peri-Urban Land Use Relationships - Strategies And Sustainability Assessment Tools For Urban-Rural Linkages) funded by the European Commission through its $6^{\text {th }}$ Framework, Contract No. 036921. The Netherlands Ministry of Agriculture, Nature and Food Quality (LNV) contributed through Kennisbasis to the writing process of this paper.

\section{References}

AALBERS, C.B.E.M. and ECKERBERG, K. (2011) Governance patterns and performance of regional strategies in peri-urban areas. Comparative analysis of seven case studies in Europe and China. PLUREL D3.3.8. Wageningen: Alterra Wageningen UR.

AALBERS, C.B.E.M. and VAN DIJK, T. (2007) JAF Remix: analysis framework. A framework for research of spatial planning and governance strategies in Rural-Urban Regions to promote sustainability of rural-urban linkages. PLUREL D3.2.1. Wageningen: Alterra Wageningen UR.

AAlbers, C.B.E.M., VAn DiJK, T., VAn DER JAGT, P.D. and WesterinK, J. (2009) Analysis of regional spatial planning and decision making strategies and their impact on land use in the urban fringe: case study of The Hague region, The Netherlands. PLUREL D3.3.1. Wageningen: Alterra.

AdOLPHSON, M. (2010) Kernel densities and mixed functionality in a multicentred urban region Environment and Planning B: Planning and Design 37(3), pp. 550-66.

AguilerA, A. and Mignot, D. (2004) Urban sprawl, polycentrism and commuting. A comparison of seven French urban areas Urban Public Economics Review 1, pp. 93-114.

BAUER, A. (2010) Assessment report on local and regional planning strategies. PLUREL Unpublished report. Leipzig: Helmholtz Centre for Environmental Research - UFZ.

BDJ (2010) Raumordnungsgesetz. Baugesetzbuch, edition 42. Bundesministerium der Justiz. Munich: Deutscher Taschenbuch Verlag.

BogunOVICH, D. (2009) From planning sustainable cities to designing resilient urban regions. WIT Transactions on Ecology and the Environment

Bramley, G., Dempdey, N., Power, S., Brown, C. and Watkins, D. (2009) Social sustainability and urban form: Evidence from five British cities Environment and Planning A 41(9), pp. 2125-42.

Breheny, M. (1993) Planning the sustainable city region Town \& Country Planning 62(4), pp. 71-75. 
BREHENY, M. (1996) Centrists, decentrists and compromisers, in JENKS, M., BURTON, E. \& Williams, K. (Eds) The compact city. A sustainable urban form?, pp. 1336. London: E \& FN Spon.

BREHENY, M. (1997) Urban compaction: Feasible and acceptable? Cities 14(4), pp. 20917.

BRIAN, S. and RodGERS, M.O. (2001) Urban form and thermal efficiency how the design of cities influences the Urban heat island effect Journal of the American Planning Association 67(2), pp. 186-98.

Briene, M., Goessen, F., MeiJ, S. VAn DER and Poel, P. (2006) Recreatie Monitor Zuid-Holland. Rotterdam: ECORYS.

Burton, E. (2001) The Compact City and Social Justice. Housing Studies Association Spring Conference. Housing, Environment and Sustainability. University of York: 18/19 April 2001.

BuYCK, J., CHERY, J.P. and JARrige, F. (2008) Analysis of spatial planning and decision making strategies and their impact on land use in the urban fringe. Montpellier case study. PLUREL D3.3.2. Paris: Alfred Peter Paysagiste.

Calthorpe, P. (1993) The Next American Metropolis: Ecology, Community, and the American Dream. New York: Princeton Architectural Press.

CAPEllo, R. and CAMAGni, R. (2000) Beyond optimal city size: An evaluation of alternative urban growth patterns Urban Studies 37(9), pp. 1479-96.

CBS (all years) Centraal Bureau voor de Statistiek. www.statline.nl Accessed November 2010.

CLG (2010) Planning Policy Statement 3: Housing. London: Communities and Local Government.

Dantzig, G. B. and SaAty, T. L. (1973) Compact City: a Plan for a Liveable Urban Environment. Compact City. San Francisco: Freeman.

De Ridder, K., Lefebre, F., Adriaensen, S., Arnold, U., Beckroege, W., Bronner, C., DamsgaArd, O., Dostal, I., Dufek, J., Hirsch, J., IntPanis, L., KoteK, Z., RAmadier, T., Thierry, A., Vermoote, S., WANiA, A. and Weber, C. (2008)

Simulating the impact of urban sprawl on air quality and population exposure in the German Ruhr area. Part I: Reproducing the base state Atmospheric Environment 42(30), pp. 7059-69.

Duany, A., Plater-Zyberk, E. and SPeck, J. (2000) Suburban Nation: The Rise of Sprawl and the Decline of the American Dream. New York: North Point Press.

EEA (2006) Urban sprawl in Europe. The ignored challenge. EEA Report No 10/2006. Copenhagen: European Environment Agency

ELNAHAS, M. M. (2003) The effects of urban configuration on urban air temperatures Architectural Science Review 46(2), pp. 135-38.

Elson, M., Walker, S., MacDonald, R. and EdGe, J. (1993) The Effectiveness of Green Belts. London: DOE, HMSO.

EMmANUEL, R. and FERNANDO, H. J. S. (2007) Urban heat islands in humid and arid climates: Role of urban form and thermal properties in Colombo, Sri Lanka and Phoenix, USA Climate Research 34(3), pp. 241-51.

Evers, A., Schulz, A. D. and Wiesner, C. (2006) Local Policy Networks in the Programme Social City -- A Case in Point for New Forms of Governance in the 
Field of Local Social Work and Urban Planning European Journal of Social Work 9(2), pp. 183-200.

EwING, R. and RonG, F. (2008) The impact of urban form on U.S. residential energy use Housing Policy Debate 19(1), pp. 1-30.

GONW (2008) Regional Spatial Strategy for the North West Region. London: Government Office for the North West.

GORDON, P. and RichARDSON, H. W. (1997) Are compact cities a desirable planning goal? Journal of the American Planning Association 63(1), pp. 95-106.

GRL (2010) Grüner Ring Leipzig. http://www.gruener-ring-leipzig.de/index.php Accessed 21 July 2010.

HAASE, A., KABISCH, S. and STEINFÜHRER, A. (2005) Reurbanisation of inner-city areas in European cities: scrutinizing a concept of urban development with reference to demographic and household change, in SAGAn, I. \& SMITH, D. M. (Eds) Society, Economy, Environment-Towards the Sustainable City, pp. 75-91. Gdansk and Poznan: Bogucki Wydawnictwo Naukowe.

HAASE, D. (2008) Urban ecology of shrinking cities: an unrecognised opportunity? Nature and Culture 3, pp. 1-8.

HAASE, D. and NuISSL, H. (2007) Does urban sprawl drive changes in the water balance and policy?. The case of Leipzig (Germany) 1870-2003 Landscape and Urban Planning 80(1-2), pp. 1-13.

Haccou, H.A., Deelstra, T., Jain, A., Pamer, V., Krosnicka, K. and De WaArd, R. (2007) MILU: Multifunctional and Intensive Land Use. Principles, Practices, Projects and Policies. Gouda: The Habiforum Foundation.

HAJER, M. and ZONNEVELD, W. (2000) Spatial planning in the network society-rethinking the principles of planning in the Netherlands European Planning Studies 8(3), pp. 337-55.

HÄUßBermanN, H. and HaILA, A. (2004) The European City: A Conceptual Framework and Normative Project, in KAZEPOV, Y. (Ed.) Cities of Europe: Changing Contexts, Local Arrangements and the Challenge to Social Cohesion, Oxford: Blackwell Publishing.

Hillman, M. (1996) In favour of the compact city, in JenKs, M., Burton, E. \& WILLIAMS, K. (Eds) The compact city. A sustainable urban form?, pp. 36-44. London: E \& FN Spon.

HoLDEN, E. (2004) Ecological footprints and sustainable urban form Journal of Housing and the Built Environment 19(1), pp. 91-109.

Holden, E. and Norland, I. T. (2005) Three challenges for the compact city as a sustainable urban form: Household consumption of energy and transport in eight residential areas in the Greater Oslo Region Urban Studies 42(12), pp. 2145-66.

Howley, P. (2009) Attitudes towards compact city living: Towards a greater understanding of residential behaviour Land Use Policy 26(3), pp. 792-98.

HOWLEY, P. (2010) 'Sustainability versus liveability': An exploration of central city housing satisfaction European Journal of Housing Policy 10(2), pp. 173-89.

Howley, P., SCOTT, M. and REDMOND, D. (2009) Sustainability versus liveability: An investigation of neighbourhood satisfaction Journal of Environmental Planning and Management 52(6), pp. 847-64. 
INSEE (2010) Les chiffres clés de Montpellier Agglomération.

http://www.insee.fr/fr/themes/document.asp?reg_id=1\&ref_id=16187\&page=synt hese/syn1004/montpellier_agglo.htm Accessed October 2010.

Jarrige, F., Soulard, C., Nougaredes, B., Laurens, L. and Sabatier, B. (2008) Les projets agri-urbains: des innovations territoriales? Exemple du bâti agricole dans l'Hérault (France), in LauRENS, F. N. D., BRYANT, L. \& LOUDIYI, S. (Eds)

Territoires, acteurs et projets: regards sur le canada, la France et ailleurs, pp. 91-97. Montréal: Editions de l'Université de Montréal.

JENKS, M. and BURTON, E. (EDS.) (1996) The compact city: a sustainable urban form? London [etc.]: E \& FN Spon.

Johnson, J. (1996) Sustainability in Scottish cities, in Jenks, M., Burton, E. \& WILliAMS, K. (Eds) The Compact City: a sustainable urban form?, pp. 31827. London: E \& FN Spon.

KNight, C. (1996) Economic and social issues, in Jenks, M., Burton, E. \& WiLliams, K. (Eds) The Compact City. A sustainable urban form?, pp. 114-21. London: E \& FN Spon.

Koomen, E., RIETVELD, P. and BACAO, F. (2009) The third dimension in urban geography: The urban-volume approach Environment and Planning B: Planning and Design 36(6), pp. 1008-25.

LiN, J. J. and YANG, A. T. (2006) Does the compact-city paradigm foster sustainability? An empirical study in Taiwan Environment and Planning B: Planning and Design 33(3), pp. 365-80.

LOIBL, W. and KÖSTL, M. (2010) Report on a methodology to delineate RUR subregions. PLUREL D 2.1.4. Seibersdorf: Austrian Research Centres.

LOIBL, W., KÖSTL, M. and STEINNOCHER, K. (2008) List of generic rural-urban region types; quantitative classification. PLUREL D2.1.2/ D2.1.3 Version V3 15/4/2008. Seibersdorf: Austrian Research Centers.

LPSA (2003) Landesentwicklungsplan 2003. Dresden: Sächsisches Staatsministerium des Innern.

LPSAH (1999) Landesentwicklungsplan des Landes Sachsen-Anhalt. Magdeburg: Ministerium für Landesentwicklung und Verkehr Sachsen-Anhalt.

LÜTKE-DALDRUP, E. (2001) Die perforierte Stadt. Eine Versuchsanordnung, Bauwelt, 24. Stadtbauwelt 150, pp. 40-45.

Martins, H., MiRANDA, A. I. and BORREGO, C. (2008) Linking urban structure and air quality. Transportation Land Use, Planning, and Air Quality - Proceedings of the 2007 Transportation Land Use, Planning, and Air Quality Conference

MoL (2009) Monitoringbericht 2008. Leipzig: Municipality of Leipzig.

MONTPELLIER-AGGLOMÉRATION (2006) Schéma de cohérence territoriale de l'Agglomération de Montpellier.

NE and CPRE (2009) Green Belts: a greener future. Cheltenham, UK: Natural England, CPRE.

Neuman, M. (2005) The compact city fallacy Journal of Planning Education and Research 25(1), pp. 11-26.

NOUgARĖDES, B. (2008) Sociabilités et modes d'habiter: le bâti viticole dans l'Hérault. Mémoire de Master II recherche "formation aux métiers de la 
recherche en sociologie", option "action publique territoire et environnement". Toulouse: Université de Toulouse II - Le Mirail.

NUISSL, H. and RINK, D. (2005) The 'production' of urban sprawl in eastern Germany as a phenomenon of post-socialist transformation Cities 22(2), pp. 123-34.

NWDA (2009) Regional Economic Strategy for the North West. Warrington: North West Development Agency.

OwENS, S. (1986) Energy, planning and urban form. Pion, distributed by Methuen.

OwENs, S. E. and RickABY, P. A. (1992) Settlements and energy revisited Built Environment 18(4), pp. 247-52.

RaVETZ, J. (1999) Urban Form and the Sustainability of Urban Systems: theory and practice in a northern conurbation., in JENKS, M., BURTON, E. \& WILLIAMS, K. (Eds) Achieving Sustainable Urban Form, London: E \& F Spon.

Ravetz, J. (2000) City-Region 2020: Integrated Planning for a Sustainable Environment. London: Earthscan.

RAVETZ, J. (2008) The city-region in time and space: Analysis of regional spatial planning and decision-making strategies, and their impact on land use in the urban fringe. Greater Manchester. PLUREL D3.3.6. Manchester: Manchester University.

Roberts, P. (2008) Sustainable Communities - Policy, Practice and Professional Development: A Model for Europe, in COOPER, I. \& SYMES, M. (Eds)

Sustainable Urban Development: Changing Professional Practice, London: Routledge.

RPH (2009) Regionaler Entwicklungsplan für die Planungsregion Halle. Halle: Regionale Planungsgemeinschaft Halle.

RPWS (2008) Regionalplan Westsachsen. Leipzig: Regionaler Planungsverband Westsachsen.

SAOS (2010) Population Statistics. Saxony-Anhalt Office of Statistics www.statistik.sachsen-anhalt.de Accessed 20 July 2010.

SAS (2010) Population Statistics, territorial status 31.07.08. Saxon Office of Statistics www.statistik.sachsen.de Accessed 20 July 2010.

SCHWEITZER, L. and ZHOU, J. (2010) Neighborhood air quality, respiratory health, and vulnerable populations in compact and sprawled regions Journal of the American Planning Association 76(3), pp. 363-71.

SCOFFHAM, E. and VALE, B. (1996) How compact is sustainable - How sustainable is compact?, in JenKs, M., Burton, E. \& Williams, K. (Eds) The Compact City a Sustainable Urban Form?, pp. 66-73. London: E and FN Spon, an imprint of Chapman and Hall.

SinN, A., HAASE, D. and WALDE, A. (2008) Analysis of regional spatial planning and decision-making strategies and their impact on landuse in the urban fringe. PLUREL D3.3.6. Leipzig: Helmholtz Centre for Environmental Research - UFZ.

SINNING, H. (2002) Leistungsfähigkeit und Grenzen kommunikativer Planungsinstrumente am Beispiel nachhaltiger Freiraumpolitik in Stadtregionen. Aachen: Rheinisch-Westfälischen Technischen Hochschule.

SonNE, W. (2009) Dwelling in the metropolis: Reformed urban blocks 1890-1940 as a model for the sustainable compact city Progress in Planning 72(2), pp. 53-149. 
StRetTon, H. (1996) Density, Efficiency and Equality in Australian Cities, in Jenks, M., Burton, E. \& Williams, K. (Eds) The Compact City. A sustainable urban form?, pp. 45-52. London: E \& FN Spon.

Thomas, L. and Cousins, W. (1996) The compact city: A successful, desirable and achievable urban form? The Compact City: A Sustainable Urban Form? , pp. 53-65.

THR (2004) Regionale woonvisie Haaglanden 2000-2015. Den Haag: Stadsgewest Haaglanden.

THR (2008) Regionaal Structuurplan. Den Haag: Stadsgewest Haaglanden.

TROY, P.N. (1996) Environmental stress and urban policy, in JENKS, M., BURTON, E. \& Williams, K. (Eds) The Compact City. A sustainable urban form?, pp. 20011. London: E \& FN Spon.

UytenHAAK, R. and MENSINK, J. (2008) Steden vol ruimte : kwaliteiten van dichtheid. Rotterdam: 010.

Van Den Berg, L., Drewett, R., Klaassen, L. H., Rossi, A. and Vijverberg, C. H. T. (1981) Urban Europe Vol. 1: a study of growth and decline. Oxford: Pergamon Press.

VAN DER WAALS, J. F. M. (2000) The compact city and the environment: A review Tijdschrift voor Economische en Sociale Geografie 91(2), pp. 111-21.

VAN RIJ, H.E., DEKKERS, J.E.C. and KoOMEN, E. (2008) Analysing the succes of open space preservation in the Netherlands: the Midden-Delfland case Tijdschrift voor Economische en Sociale Geografie 99(1), pp. p.115-25.

VID (2008) Verkeers Informatie Dienst www.vid.nl Accessed 15 August 2010.

VRies, S. DE, Staritsky, I., Clement, J., Kiers, M. and Roos-Klein LankHorst, J. (2011) Vraaggerichte recreatieplanning op regionaal niveau; naar een betere afstemming van geboden op gevraagde mogelijkheden voor recreëren in het groen middels AVANAR-plus. Alterra-rapport 2093. Wageningen: Alterra Wageningen UR.

Ward, K., Fagan, C., McDowell, L., Perrons, D. and Ray, K. (2010) Class transformation and work-life balance in urban britain: The case of manchester Urban Studies 47(11), pp. 2259-78.

WILLIAMS, K. (1999) Urban intensification policies in England: Problems and contradictions Land Use Policy 16(3), pp. 167-78.

WiLliams, K., Burton, E. and JenKs, M. (1996) Achieving the compact city through intensification The Compact City a Sustainable Urban Form?

Wood, R. and RAVETZ, J. (2000) Recasting the Urban Fringe Landscape Design 294(10), pp. 13-16.

ZONNEVELD, W. (2005) In search of conceptual modernization: The new Dutch 'national spatial strategy' Journal of Housing and the Built Environment 20(4), pp. 42543.

ZonNeVELD, W. and Verwest, F. (2005) Tussen droom en retoriek : de conceptualisering van ruimte in de Nederlandse planning. Den Haag: Ruimtelijk Planbureau. 
Table 1: Overview of characteristics and sustainability claims of the compact and the dispersed city

\begin{tabular}{|c|c|c|c|}
\hline $\begin{array}{l}\text { Sustainability } \\
\text { aspect }\end{array}$ & Indicator & Compact city & Dispersed city \\
\hline \multirow[t]{10}{*}{ Social } & Housing type & $\begin{array}{l}\text { High density, multi-storey housing. } \\
\text { Mostly apartments. Less private } \\
\text { ownership. Lack of affordable } \\
\text { housing (Burton, 2001). }\end{array}$ & $\begin{array}{l}\text { Urban sprawl, single houses. } \\
\text { Mainly private house ownership. }\end{array}$ \\
\hline & Quality of life & $\begin{array}{l}\text { Vicinity of services, education, } \\
\text { cultural activities, work, } \\
\text { countryside. Less travelling time } \\
\text { (Howley, 2009). }\end{array}$ & $\begin{array}{l}\text { Sense of freedom, ownership, } \\
\text { quietness, suburbia, } \\
\text { security/safety is important. } \\
\text { People are happier at lower } \\
\text { densities (Bramley et al., 2009). }\end{array}$ \\
\hline & $\begin{array}{l}\text { Social justice } \\
\text { (equity) }\end{array}$ & $\begin{array}{l}\text { Houses with gardens are } \\
\text { expensive. High-density areas } \\
\text { generally have low-income } \\
\text { population. However, buying a car } \\
\text { is not needed. }\end{array}$ & $\begin{array}{l}\text { House with a garden feasible for } \\
\text { many. Most people prefer to live } \\
\text { low-density (Burton, 2001; } \\
\text { Gordon \& Richardson, 1997). } \\
\text { However, a car is indispensible } \\
\text { (Burton, 2001). }\end{array}$ \\
\hline & $\begin{array}{l}\text { Home grown } \\
\text { food }\end{array}$ & Community allotment gardens. & $\begin{array}{l}\text { Opportunities in one's own } \\
\text { garden (Troy, 1996). }\end{array}$ \\
\hline & $\begin{array}{l}\text { Sense of } \\
\text { community }\end{array}$ & $\begin{array}{l}\text { More sense of community, if } \\
\text { shared facilities can be achieved } \\
\text { (Johnson, 1996; Ravetz, 1999). } \\
\text { Reduced social segregation } \\
\text { (Burton 2001). }\end{array}$ & $\begin{array}{l}\text { Low sense of community } \\
\text { (Bramley et al., 2009); } \\
\text { individualism and isolation. } \\
\text { However, gardens are source of } \\
\text { interaction (Bramley et al., 2009) }\end{array}$ \\
\hline & Safety & More violence (Burton, 2001). & $\begin{array}{l}\text { Low sense of community may } \\
\text { lead to feelings of unsafety } \\
\text { (building fences). }\end{array}$ \\
\hline & $\begin{array}{l}\text { Children's } \\
\text { play }\end{array}$ & Public playgrounds. & $\begin{array}{l}\text { In the garden and on the street. } \\
\text { Larger public playgrounds. }\end{array}$ \\
\hline & $\begin{array}{l}\text { Recreation } \\
\text { and leisure }\end{array}$ & $\begin{array}{l}\text { (Small to large) urban parks, sports } \\
\text { grounds, cemeteries, allotments } \\
\text { and countryside. }\end{array}$ & $\begin{array}{l}\text { Private garden and for that reason } \\
\text { less travel for leisure (Holden \& } \\
\text { Norland, 2005), (large) urban } \\
\text { parks are not always provided for, } \\
\text { sports grounds, cemeteries. }\end{array}$ \\
\hline & Countryside & $\begin{array}{l}\text { Close for more urbanites (Aalbers } \\
\text { et al., 2009). }\end{array}$ & Far away for many urbanites. \\
\hline & $\begin{array}{l}\text { Urban-rural } \\
\text { relations }\end{array}$ & $\begin{array}{l}\text { City depends on countryside for } \\
\text { recreational space. }\end{array}$ & $\begin{array}{l}\text { Rural communities are annexed } \\
\text { by the city. }\end{array}$ \\
\hline \multirow[t]{3}{*}{ Environment } & $\begin{array}{l}\text { Exhaust } \\
\text { emissions }\end{array}$ & $\begin{array}{l}\text { Lower total emission levels } \\
\text { (Martins et al., 2008), but higher } \\
\text { concentration of fine dust and } \\
\text { more people exposed (Schweitzer } \\
\& \text { Zhou, 2010). }\end{array}$ & $\begin{array}{l}\text { Higher total emission levels, but } \\
\text { lower concentration of fine dust } \\
\text { (De Ridder et al., 2008). }\end{array}$ \\
\hline & Noise & $\begin{array}{l}\text { More nuisance (Van Der Waals, } \\
\text { 2000) }\end{array}$ & Less nuisance \\
\hline & Energy & $\begin{array}{l}\text { Lower energy use per household } \\
\text { (Holden, 2004). }\end{array}$ & $\begin{array}{l}\text { Higher energy use per household } \\
\text { (Ewing \& Rong, 2008), but more } \\
\text { possibilities for solar energy } \\
\text { (Owens, 1986). }\end{array}$ \\
\hline
\end{tabular}




\begin{tabular}{|c|c|c|c|}
\hline \multirow{5}{*}{$\begin{array}{l}\text { Sustainability } \\
\text { aspect }\end{array}$} & Indicator & Compact city & Dispersed city \\
\hline & $\begin{array}{l}\text { Urban heat } \\
\text { island effect }\end{array}$ & $\begin{array}{l}\text { High density has lower urban heat } \\
\text { island effect in warm climates } \\
\text { (Elnahas, 2003; Emmanuel \& } \\
\text { Fernando, 2007) }\end{array}$ & $\begin{array}{l}\text { Higher (Brian \& Rodgers, 2001), } \\
\text { but vegetation can mitigate. }\end{array}$ \\
\hline & $\begin{array}{l}\text { Water } \\
\text { management }\end{array}$ & $\begin{array}{l}\text { More complex because of high } \\
\text { proportion of sealed surface (Troy, } \\
\text { 1996) and higher concentration of } \\
\text { pollutants. }\end{array}$ & $\begin{array}{l}\text { More space for water storage and } \\
\text { infiltration, higher water } \\
\text { consumption (irrigation of } \\
\text { gardens). }\end{array}$ \\
\hline & Green space & Emphasis on public green space. & Emphasis on private green space. \\
\hline & $\begin{array}{l}\text { Green space at } \\
\text { risk }\end{array}$ & $\begin{array}{l}\text { Urban green space at risk from } \\
\text { construction. }\end{array}$ & $\begin{array}{l}\text { Peri-urban green space at risk } \\
\text { from urbanisation and commercia } \\
\text { use of the area. }\end{array}$ \\
\hline \multirow[t]{5}{*}{ Economic } & Infrastructure & $\begin{array}{l}\text { Efficient in roads, sewage system } \\
\text { and other services. }\end{array}$ & $\begin{array}{l}\text { More infrastructure needed. } \\
\text { Suburb to suburb transportation } \\
\text { through highways (Gordon \& } \\
\text { Richardson, 1997). }\end{array}$ \\
\hline & Transport & $\begin{array}{l}\text { Emphasis on public transport } \\
\text { (Burton, 2001), cycling and } \\
\text { walking, but cars congest streets } \\
\text { (Williams et al., 1996). }\end{array}$ & $\begin{array}{l}\text { Emphasis on private car use. 'A } \\
\text { car is freedom' (e.g. (Knight, } \\
\text { 1996) }\end{array}$ \\
\hline & $\begin{array}{l}\text { Solution to } \\
\text { traffic jams }\end{array}$ & $\begin{array}{l}\text { Efficient and finely mazed public } \\
\text { transport system. }\end{array}$ & $\begin{array}{l}\text { Extensive road network. } \\
\text { Suburbanisation shifts traffic } \\
\text { away from core areas (Gordon } \\
\text { and Richardson, 1997). }\end{array}$ \\
\hline & $\begin{array}{l}\text { Construction } \\
\text { costs and } \\
\text { house prices }\end{array}$ & High (Howley, 2009). & Lower. \\
\hline & $\begin{array}{l}\text { Economic } \\
\text { activity }\end{array}$ & $\begin{array}{l}\text { High densities foster urban } \\
\text { production and enterprise } \\
\text { investment (Lin and Yang, 2006). }\end{array}$ & More space for initiative. \\
\hline \multirow[t]{4}{*}{ Resilience } & $\begin{array}{l}\text { Land } \\
\text { consumption }\end{array}$ & $\begin{array}{l}\text { Efficient. More emphasis on } \\
\text { multifunctional and efficient } \\
\text { landuse. }\end{array}$ & Consuming. \\
\hline & $\begin{array}{l}\text { Flood risk } \\
\text { management }\end{array}$ & $\begin{array}{l}\text { High vulnerability due to } \\
\text { concentration. }\end{array}$ & Lower vulnerability. \\
\hline & Shrinkage & Easier to adapt to shrinkage. & $\begin{array}{l}\text { More difficult to adapt to } \\
\text { shrinkage. }\end{array}$ \\
\hline & Future options & $\begin{array}{l}\text { More flexibility with respect to } \\
\text { landuse pattern (Van Der Waals, } \\
2000 \text { ). }\end{array}$ & Less flexibility. \\
\hline
\end{tabular}


Table 2: Shape indices and ranks (of 375 European regions, highest value rank $=1$, lowest $=375$ ) of the sample regions according to Loibl et al. (2008) (cf. Table 4), adjusted by the authors. Density values are from Loibl and Köstl (2010).

\begin{tabular}{|c|c|c|c|c|}
\hline Urban region name & $\begin{array}{l}\text { The Hague } \\
\text { Region }\end{array}$ & Leipzig-Halle & $\begin{array}{l}\text { Greater } \\
\text { Manchester }\end{array}$ & $\begin{array}{l}\text { Montpellier } \\
\text { Agglomération }\end{array}$ \\
\hline Country & Netherlands & Germany & $\begin{array}{l}\text { United } \\
\text { Kingdom }\end{array}$ & France \\
\hline RUR* name & $\begin{array}{l}\text { Rotterdam- } \\
\text { Haaglanden }\end{array}$ & Leipzig-Halle & $\begin{array}{l}\text { Manchester- } \\
\text { Liverpool }\end{array}$ & Montpellier \\
\hline RUR type & $\begin{array}{l}\text { Urban } \\
\text { polycentric }\end{array}$ & $\begin{array}{l}\text { Urban } \\
\text { polycentric }\end{array}$ & $\begin{array}{l}\text { Urban } \\
\text { polycentric }\end{array}$ & $\begin{array}{l}\text { Monocentric } \\
\text { large }\end{array}$ \\
\hline Number of urban polygons & 36 & 22 & 82 & 11 \\
\hline Conurbation area 2000 [ha] & 56,700 & 37,600 & 228,400 & 14,700 \\
\hline Urban fabric area 2000 [ha] & 23,801 & 20,320 & 131,350 & 8,443 \\
\hline $\begin{array}{l}\text { Growth urban fabric area 1990-2000 [ha] } \\
\text { Rank (1 to 375) }\end{array}$ & $\begin{array}{r}4,131 \\
8\end{array}$ & $\begin{array}{r}2,470 \\
17\end{array}$ & $\begin{array}{r}2,122 \\
20\end{array}$ & $\begin{array}{r}1,020 \\
62\end{array}$ \\
\hline Total core area index TCAI ** & $\begin{array}{r}44.6 \\
42\end{array}$ & $\begin{array}{r}43.2 \\
47\end{array}$ & $\begin{array}{r}45.6 \\
41\end{array}$ & $\begin{array}{r}30.9 \\
147\end{array}$ \\
\hline Urban fabric land consumption per capita & 188 & 371 & 289 & 287 \\
\hline Urban density RUR (people per ha urban) & 46.75 & 26.53 & 35.18 & 33.65 \\
\hline Total density RUR (people per ha) & 12.00 & 2.98 & 8.73 & 1.69 \\
\hline GDP 2000 & $27,216.8$ & $17,931.7$ & $23,971.9$ & $19,471.6$ \\
\hline
\end{tabular}

*RUR: rural urban region.

**TCAI: an indicator of compactness and centrality: value 0 indicates absence of core area and values close to 100 indicates that the core covers most of the urban fabric area. 
Table 3: Population growth in Montpellier Agglomération

\begin{tabular}{|c|c|c|c|c|c|c|}
\hline $\begin{array}{l}\text { Montpellier city region } \\
\text { Population (INSEE, 2010) }\end{array}$ & 1881 & 1954 & 1975 & 1990 & 1999 & 2006 \\
\hline Montpellier city & 56,005 & 97,501 & 191,354 & 208,103 & 225,511 & 251,634 \\
\hline $\begin{array}{l}\text { Montpellier Agglomération } \\
31 \text { municipalities } \\
438 \mathrm{~km}^{2}\end{array}$ & 78,921 & 128,880 & 250,000 & 318,00 & 367,000 & 406,139 \\
\hline $\begin{array}{l}\text { Aire urbaine de Montpellier } \\
93 \text { municipalities } \\
1,438 \mathrm{~km}^{2}\end{array}$ & 91,324 & 148,472 & 284,541 & 388,747 & 459,916 & 509,835 \\
\hline
\end{tabular}


Table 4: differentiated growth and decline in urban and peri-urban areas in percent (SAS, 2010).

\begin{tabular}{|l|l|l|}
\hline & $\mathbf{1 9 9 0 - 2 0 0 0}$ & $\mathbf{2 0 0 0 - 2 0 0 6}$ \\
\hline Leipzig District (around Leipzig) & +0.3 & -4.8 \\
\hline Leipzig (core city) & -11.5 & +2.4 \\
\hline Saale District (around Halle) & +4.2 & -5.2 \\
\hline Halle (core city) & $-24 \%$ & \\
\hline
\end{tabular}


Table 5: Modes of transportation used by inhabitants of major cities in Randstad and The Hague Region (*). Source: CBS.

\begin{tabular}{|c|c|c|c|c|c|c|c|}
\hline \multirow{2}{*}{$\begin{array}{l}\text { Average 2002-2003 } \\
\text { Transport mode }\end{array}$} & \multicolumn{7}{|c|}{$\%$ of total transport per capita per day in $\mathrm{km}$} \\
\hline & Netherlands & Amsterdam & Utrecht & Rotterdam & The Hague* & Delft* & Zoetermeer* \\
\hline Car & $75.6 \%$ & $56.9 \%$ & $63.7 \%$ & $66.4 \%$ & $64.9 \%$ & $65.6 \%$ & $70.1 \%$ \\
\hline Public transport & $12.0 \%$ & $27.5 \%$ & $23.4 \%$ & $23.2 \%$ & $21.5 \%$ & $21.3 \%$ & $16.5 \%$ \\
\hline Moped & $0.5 \%$ & $0.4 \%$ & $0.7 \%$ & $0.4 \%$ & $0.6 \%$ & $0.2 \%$ & $0.4 \%$ \\
\hline Cycling and walking & $9.2 \%$ & $12.5 \%$ & $9.5 \%$ & $8.1 \%$ & $11.1 \%$ & $11.1 \%$ & $10.8 \%$ \\
\hline Other & $2.7 \%$ & $2.7 \%$ & $2.6 \%$ & $1.9 \%$ & $1.9 \%$ & $1.9 \%$ & $2.2 \%$ \\
\hline $\begin{array}{l}\text { Distance travelled } \\
\text { per capita per day } \\
(\mathbf{k m})\end{array}$ & 31.86 & 27.98 & 37.28 & 28.4 & 25.12 & 30.15 & 29.09 \\
\hline $\begin{array}{l}\text { Number of } \\
\text { inhabitants } 1 \\
\text { January } 2003\end{array}$ & 16.192 .572 & 736.562 & 265.151 & 599.651 & 463.826 & 96.588 & 112.594 \\
\hline
\end{tabular}


Table 6: Comparison of the expressions of compact city thinking in the sample regions

\begin{tabular}{|c|c|c|c|c|}
\hline & Montpellier & Leipzig-Halle & Manchester & The Hague Region \\
\hline Dynamics & $\begin{array}{l}\text { Correcting earlier } \\
\text { urban sprawl }\end{array}$ & $\begin{array}{l}\text { Adjusting to } \\
\text { population } \\
\text { shrinkage, re- } \\
\text { urbanisation }\end{array}$ & $\begin{array}{l}\text { History of strong } \\
\text { planning, but a flow } \\
\text { of larger commercial } \\
\text { and institutional } \\
\text { development in spite } \\
\text { of urban } \\
\text { containment policy }\end{array}$ & $\begin{array}{l}\text { History of strong } \\
\text { planning. Stabilizing } \\
\text { population, but } \\
\text { demographic shift } \\
\text { with changing } \\
\text { recreational needs }\end{array}$ \\
\hline Concepts & $\begin{array}{l}\text { Compact city, } \\
\text { densification, } \\
\text { polycentrism } \\
\text { (decentralized } \\
\text { concentration), } \\
\text { proximity, limits } \\
\text { urban development. }\end{array}$ & $\begin{array}{l}\text { Central places } \\
\text { (metropolitan } \\
\text { network), } \\
\text { Inner city building, } \\
\text { brownfield } \\
\text { development, Green } \\
\text { Ring }\end{array}$ & $\begin{array}{l}\text { Compact city, Green } \\
\text { Belt, brownfield } \\
\text { development }\end{array}$ & $\begin{array}{l}\text { Compact city, } \\
\text { polycentrism, } \\
\text { satellite city, inner } \\
\text { city building, TOD, } \\
\text { Buffer zones }\end{array}$ \\
\hline Trade-offs & $\begin{array}{l}\text { Sprawl led to } \\
\text { landscape } \\
\text { degradation. } \\
\text { Preventing sprawl } \\
\text { leads to social } \\
\text { problems in villages }\end{array}$ & $\begin{array}{l}\text { Suburbanization led } \\
\text { to inner city } \\
\text { degradation. }\end{array}$ & $\begin{array}{l}\text { Jumping the Green } \\
\text { Belt combined with } \\
\text { 'urban trap': the } \\
\text { poor stay behind in } \\
\text { the city. } \\
\text { 'Conservation only' } \\
\text { limits landscape } \\
\text { diversity and } \\
\text { dynamics of change. }\end{array}$ & $\begin{array}{l}\text { Strong protection of } \\
\text { peri-urban but too } \\
\text { few urban parks. } \\
\text { High congestion. }\end{array}$ \\
\hline Strategies & $\begin{array}{l}\text { Ban on civil housing } \\
\text { in farming areas, } \\
\text { joint planning } \\
\text { guidelines for } \\
\text { municipalities, } \\
\text { including } \\
\text { densification targets. }\end{array}$ & $\begin{array}{l}\text { Inner city renewal, } \\
\text { greening the city, } \\
\text { developing peri- } \\
\text { urban green space. }\end{array}$ & $\begin{array}{l}\text { Social mix in } \\
\text { housing. }\end{array}$ & $\begin{array}{l}\text { Multifunctional land } \\
\text { use, improving } \\
\text { public transport, } \\
\text { improving } \\
\text { accessibility of peri- } \\
\text { urban, variety in } \\
\text { housing. }\end{array}$ \\
\hline
\end{tabular}

